Research Article

Human and Medical Genetics

\title{
Three Mexican Families with $\beta$ thalassemia intermedia with different molecular basis
}

Lourdes del Carmen Rizo de la Torre ${ }^{1}$ iD, Francisco Javier Perea Díaz ${ }^{2}$, Bertha Ibarra Cortés ${ }^{3}$, Víctor Manuel Rentería López ${ }^{2}$, Josefina Yoaly Sánchez López ${ }^{2}$, Francisco Javier Sánchez Anzaldo ${ }^{4}$, María Teresa Magaña Torres ${ }^{2}$, Katia Gonnet ${ }^{5}$, Catherine Badens ${ }^{5}$ and Nathalie Bonello-Palot ${ }^{5}$

${ }^{1}$ Instituto Mexicano del Seguro Social, Centro de Investigación Biomédica de Occidente, División de Medicina Molecular, Independencia Oriente, Guadalajara Jalisco, México.

${ }^{2}$ Instituto Mexicano del Seguro Social, Centro de Investigación Biomédica de Occidente, División de Genética, Independencia Oriente, Guadalajara Jalisco, México.

${ }^{3}$ Universidad de Guadalajara, Centro Universitario de Ciencias de la Salud, Instituto de Genética Humana "Dr Enrique Corona Rivera", Independencia Oriente, Guadalajara Jalisco, México.

${ }^{4}$ Laboratorios Ruiz, Puebla de Zaragoza, Puebla, México.

${ }^{5}$ Hôpital d' enfants de la Timone, Déparement de Génétique, Laboratoire de Génétique Moléculaire, Marseille, France.

\begin{abstract}
Beta thalassemia ( $\beta$-thal) is a frequent monogenic disease, is clinically and molecularly heterogeneous. This study described molecular and laboratory findings for three Mexican patients with $\beta$-thal intermedia phenotype and their relatives. Three Mexican families were studied for presenting $\beta$-thal intermedia, ARMS-PCR and Gap-PCR were performed to screen for common mutations, Sanger sequencing for rare or new alleles, and MLPA for identifying deletions and or duplications. In all three families we observed, in heterozygote condition, the mutation c.118C > T (p.Gln39*) also known as codon 39(C > T) in the $\beta$ globin gene $(H B B)$ associated with a novel molecular defect: a new duplication of the alpha globin gene cluster, a new deletion that includes the loss of exon 3 of HBB and finally a novel mutation in the 3'UTR of HBB (HBB: c. ${ }^{*} 132 \mathrm{C}>\mathrm{A}$ ). We report three Mexican families with beta thalassemia intermedia due to different molecular basis; a new single nucleotide mutation involving the last nucleotide of the $\beta$-globin chain transcript; and two possible new DNA rearrangements, an $\alpha$ cluster duplication, and a partial $\beta$ gene deletion.
\end{abstract}

Keywords: Thalassemia intermedia, Mexican population, $\beta$ globin gene, new mutations, alpha-globin gene duplication.

Received: Febuary 07, 2019; Accepted: November 01, 2019.

\section{Introduction}

Beta thalassemia ( $\beta$-thal) is one of the most frequent worldwide monogenic diseases, it is an autosomal recessive disorder, characterized by reduced $\left(\beta^{+}, \beta^{++}\right)$or absence $\left(\beta^{0}\right)$ of hemoglobin's beta subunit (Thein, 2018). HBB gene mutations are the cause for this disease, to date there are near 300 reported $\beta$-thal alleles (http://globin.cse.psu.edu/), these mutations can be divided in three main groups: a) transcriptional mutations that include promoter regulatory elements or 5' UTR; b) RNA processing mutations involving splicing junction, consensus and cryptic sequences,

Send correspondence to: Nathalie Bonello Palot. Hôpital d' enfants de la Timone, Déparement de Génétique, Laboratoire de Génétique Moléculaire, 264 Rue Saint-Pierre, 13385, Marseille, France. E-mail Nathalie.BONELLO@ap-hm.fr poly A signal and 3' UTR; and c) translation mutations which include initiation codon substitutions, nonsense and frameshift mutations (Thein, 2018). Although single nucleotide mutations represent the vast majority of $\beta$-thalassemias, deletions involving $H B B$ gene, or its regulating sequences have also been associated to this pathology ( $\mathrm{Pa}-$ trinos GP et al., 2004). Despite being an autosomal recessive inherited condition, some forms of $\beta$-thal are inherited dominantly ( $\beta^{\mathrm{D}}$ alleles), so is the case of nonsense or frameshift mutations in exon three that result in the formation of a premature termination codon and therefore the production of unstable $\beta$-globin chains that precipitate along with the free $\alpha$-globin chains in the erythroid precursor causing premature death and ineffective erythropoiesis (Thein, 2018; Rawa et al., 2017). 
$\beta$-thal is classified according to severity as minor, major and intermedia (Thein and Wood et al., 2009; Thein, 2018). The minor form corresponds to the simple heterozygote condition whereas the beta-thalassemia major type refers to the more severe disorder with transfusion dependency as a result of the inheritance of two $\beta^{0}$ alleles. $\beta$-thal intermedia comprises a wide range of clinical features and is mainly characterized by occasional blood transfusions; $\beta$-thal intermedia is observed in different molecular forms such as, two $\beta$-thal alleles $\left(\beta^{0} / \beta^{+/+}, \beta^{0} / \beta^{0}\right)$, one $\beta$-thal allele and additional copies of $\alpha$-globin genes $\left(\beta^{0} / \beta^{\mathrm{A}} ; \alpha \alpha \alpha / \alpha \alpha\right.$, $\alpha \alpha \alpha \alpha / \alpha \alpha, \alpha \alpha \alpha \alpha / \alpha \alpha \alpha)$ or the presence of a single dominant $\beta$-thal allele $\left(\beta^{\mathrm{D}} / \beta^{\mathrm{A}}\right)$ (Origa et al., 2014; Ben-Salah et al., 2017, Clark et al., 2018).

The pathophysiology of this disease is the outcome of an imbalanced ratio of $\alpha$ - and non- $\alpha$-globin chains (excess of $\alpha$-globin chains), and the severity depends on three different mechanisms. First, the type of $\beta$ allele $\left(\beta^{0}, \beta^{+}\right.$or $\left.\beta^{++}\right)$, correlated to the amount of residual $\beta$-globin chains (Mettananda et al., 2015; Ben-Salah et al., 2017; Shang and Xu 2017; Zhong et al., 2018). Second is the co-inheritance of alpha globin locus defect, either an alpha-thalassemia deletion ( $\alpha$-thal) which is often observed in $\beta$-thal patients, resulting as a positive modifier or, conversely, the presence of additional copies of $H B A 2$ or $H B A 1$ genes which causes a more severe form of $\beta$-thal (Ben-Salah et al., 2017; Theodoridou et al., 2018; Clark et al., 2018; Harteveld et al., 2008). And third is the presence of genetic variants associated with increased fetal hemoglobin $(\mathrm{HbF})$ production. For instance, HBG2:c. $-211 \mathrm{C}>\mathrm{T}(X m n 1-158 \mathrm{C}>\mathrm{T}) \mathrm{a}$ single nucleotide polymorphism in the $H B G 2$ promoter is known to be a HbF inducer (Mettananda and Higgs 2018; Ngo and Steinberg 2015; Sripichai and Fucharoen 2016).

Beta thalassemic alleles have been previously studied in Mexican population, a total of 21 different mutations represent the molecular spectrum of this disease in Mexico (Rizo-de la Torre et al., 2017). The aim of this paper is to report for the first time three Mexican families with $\beta$-thalassemia intermedia due to the combination of the common allele $(H B B$ : c. $118 \mathrm{C}>\mathrm{T})$ and a novel molecular defect.

\section{Subjects and Methods}

\section{Subjects}

Three thalassemia intermedia patients and their families were included in this study.

Family 1 is composed by seven members originally from the state of Jalisco, the index case is a 25 -year-old female. Family 2 is from Oaxaca and consists of a 5-year-old girl and her parents. Family 3 is from Guanajuato and composed of three members, a 28-year-old male and his two children.

All subjects signed informed consent for hematological, biochemical and molecular studies. All procedures were performed in accordance with the standards of the local ethics committee of the Instituto Mexicano del Seguro Social (Mexican Institute of Social Security) and with the 1964 Helsinki declaration.

\section{Hematological and biochemical analysis}

Peripheral blood $(10 \mathrm{~mL})$ was collected in EDTA tubes. The hematological data were obtained by electronic counter (ADVIA2120i; Siemens Healthcare, Erlangen, Germany); the biochemical analysis was performed by conventional methods ( $\mathrm{HbF}$ by alkaline denaturation, $\mathrm{HbA}_{2}$ by microchromatography with diethylaminoethyl DEAE cellulose-Sigma Aldrich and, electrophoresis in cellulose acetate) (Huisman and Jonxis, 1977).

\section{Molecular analysis}

DNA samples were isolated by salting-out procedure (Miller et al., 1988). The genotyping process comprises the routine thalassemia screening: ARMS-PCR for $H B B$ known mutations (Old et al., 1990), gap-PCR for $\delta \beta$-thalassemia Spanish type (Vives-Corrons et al., 1992) and common alpha-thalassemia deletions (Liu et al., 2000). Furthermore, $H B B, H B A 2$ and $H B A 1$ genes were analyzed by Sanger sequencing, using BigDye ${ }^{\circledR}$ Terminator kit v3.1 and Applied Biosystems 3500 Series Genetic Analyzer (Applied Biosystems); and multiple ligation-dependent probe amplification using SALSA ${ }^{\circledR}$ MLPA ${ }^{\circledR}$ probemix P102HBB and P140HBA following the manufacturer's recommendations (MRC-Holland) for all the individuals described above.

\section{Results}

All three propositus were suspected of intermedia thalassemia. They exhibited mild to severe anemia, and unusual elevated $\mathrm{HbF}$. We suspected the presence of at least two thalassemic alleles $(\alpha, \beta$ or $\delta$ ), and/or hereditary persistence of fetal hemoglobin. Hematological, biochemical and molecular data are shown in Table 1.

Family 1

The proposita (II-3) and her two sisters (II-1 and II-4) presented a profile typical of thalassemia intermedia (Table $1)$ whereas the phenotype of her parents does not entirely resemble a $\beta$-thal carrier, despite both of them presented mild anemia. Microcytosis and hypochromia were only observed in her mother (I-2), who also had borderline $\mathrm{HbA}_{2}$. Her father presented macrocytosis, low $\mathrm{HbA}_{2}$ and normal $\mathrm{HbF}$.

We found by Sanger sequencing the mutation $H B B$ : c. $118 \mathrm{C}>\mathrm{T}$ (p.Gln39*) (or $\beta 39 \mathrm{C}>\mathrm{T}$ ) in heterozygous condition in her mother (I-2) and the three affected members (II-1, II-3 and II-4). The second molecular defect observed in the three affected patients was a large duplication in $\alpha$ cluster that includes the regulatory HS-40 region as well as the genes $H B Z, H B P Z, H B M, H B P A 1, H B A 2$ and $H B A 1$ : 
16p13.3 (?-037132)_(167890-169744) (Figure 1A). This molecular defect was inherited from her father and transmitted to 4 members of the family (3 affected (II-1, II-3 and II-4) and one unaffected (II-2)). II-2 presented subnormal $\mathrm{MCV}$ and $\mathrm{MCH}$ (Table 1, Figure 1A).
Family 2

$\beta$ Thalassemia intermedia phenotype was observed in the 5-year-old proposita (II-1) with a HbF value remarkably increased $(80.5 \%)$. By analyzing independent pheno-

A)

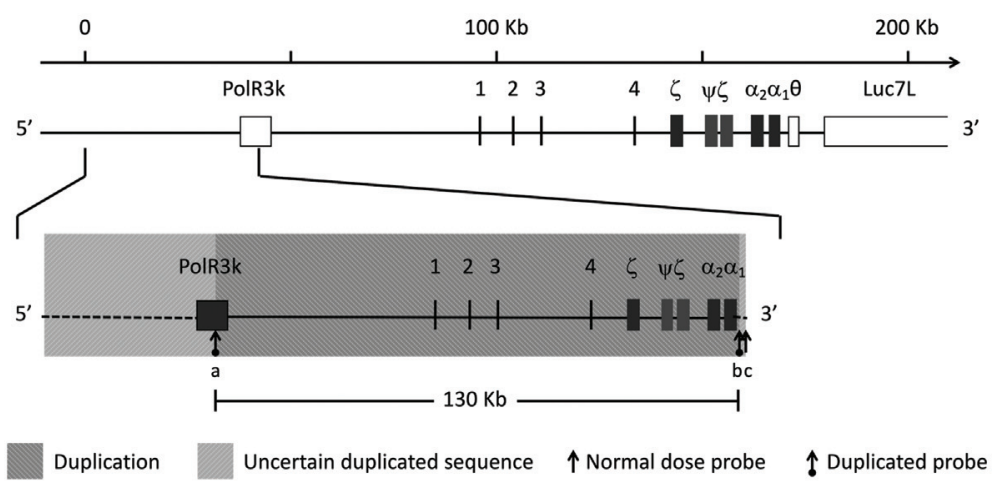

B)
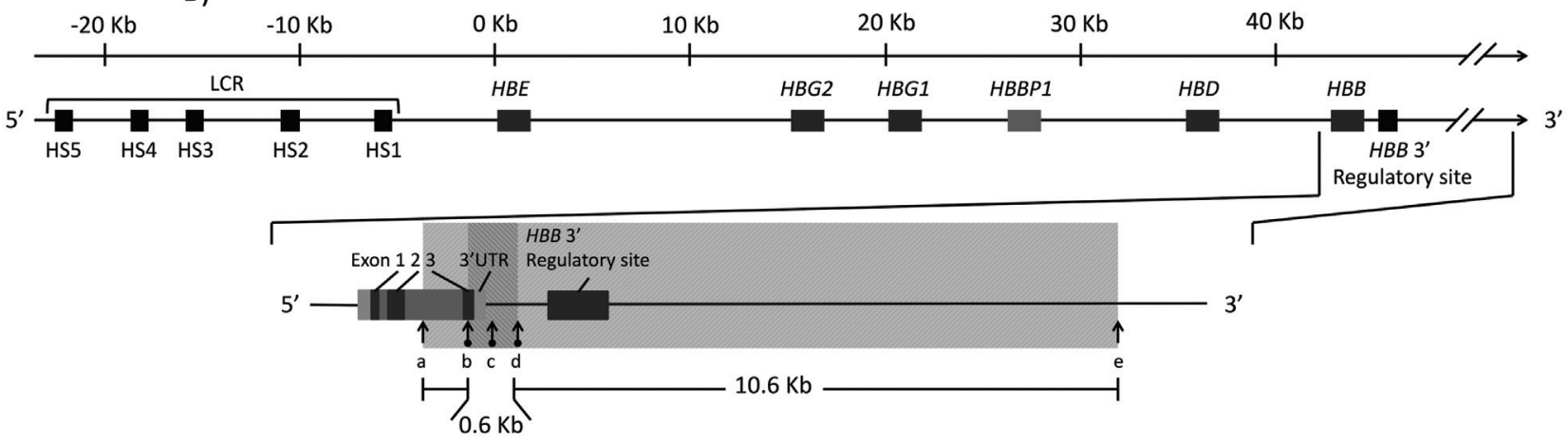

Deletion Uncertain deleted sequence $\quad \uparrow$ Normal dose probe $\quad \uparrow$ Reduced probe

C)
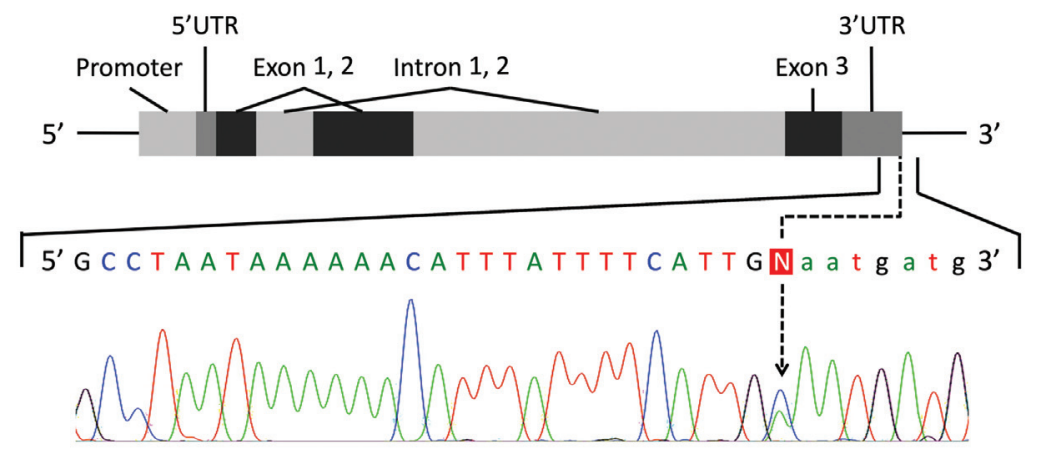

Figure 1 - Schematic representation of three globin gene mutations associated with $H B B$.c: $118 \mathrm{C}>\mathrm{T}$ in patients with $\beta$-thal intermedia. A) $\alpha$-cluster duplication from Family 1. Duplication is shown in dark grey shade, uncertain breakpoints are indicated in light grey shade; MCS-R sequences are numbered from 1-4; involved MLPA probes are specified by (a) 463 bp 19236-L25316, (b) 283 bp 04638-L23602, and (c) 310 bp 04639-L04020. B) HBB 3' deletion from Family 2. Deletion is indicated in dark grey shade, uncertain breakpoints are shown in light grey shade involved MLPA probes are presented by (a) 196 bp 05833-L05335, (b), 166 bp 11884-L12684 (c) 206 bp 11885-L13080, (d) 173 bp 05836-L06321; (e) 274 bp 11980-L12803. C) HBB:c. ${ }^{*} 132 \mathrm{C}>$ A point mutation found in Family 3. Nucleotide change is indicated with an arrow. Nucleotides in capital letters represent transcribing sequence. 
Table 1 - Hematological, biochemical and molecular data of three Mexican families with $\beta$-thal intermedia.

\begin{tabular}{|c|c|c|c|c|c|c|c|c|c|c|}
\hline Subject & Gender/Age & $\begin{array}{c}\mathrm{RBC} \\
\left(10^{12} / \mathrm{L}\right)\end{array}$ & $\begin{array}{c}\mathbf{H b} \\
(\mathrm{g} / \mathrm{dL})\end{array}$ & $\begin{array}{c}\text { MCV } \\
\text { (fL) }\end{array}$ & $\begin{array}{c}\mathrm{MCH} \\
\text { (pg) }\end{array}$ & $\begin{array}{c}\mathrm{HbA}_{2} \\
(\%)\end{array}$ & $\begin{array}{l}\mathrm{HbF} \\
(\%)\end{array}$ & $\beta$ Genotype & $\alpha$ Genotype & $\gamma$ Genotype* \\
\hline \multicolumn{11}{|l|}{ Family 1} \\
\hline $\mathrm{I}-1^{\S}$ & $\mathrm{M} / 48$ & 3.0 & 10.5 & 100.0 & 33.3 & 1.8 & 1.6 & $\beta^{\mathrm{A}} / \beta^{\mathrm{A}}$ & $\alpha \alpha \alpha \alpha / \alpha \alpha$ & $\mathrm{C} / \mathrm{C}$ \\
\hline $\mathrm{I}-2$ & $\mathrm{~F} / 46$ & 5.1 & 10.6 & 65.5 & 20.8 & 3.3 & 2.2 & $\beta^{39} / \beta^{\mathrm{A}}$ & $\alpha \alpha / \alpha \alpha$ & $\mathrm{C} / \mathrm{T}$ \\
\hline II $-1^{\dagger(I I-1 \uparrow \S)}$ & $\mathrm{F} / 33$ & 1.8 & 4.8 & 85.1 & 26.8 & 3.8 & 11.7 & $\beta^{39} / \beta^{\mathrm{A}}$ & $\alpha \alpha \alpha \alpha / \alpha \alpha$ & $\mathrm{C} / \mathrm{C}$ \\
\hline II-2 & $\mathrm{F} / 32$ & 5.3 & 13.9 & 80.3 & 26.1 & 1.1 & 1.7 & $\beta^{\mathrm{A}} / \beta^{\mathrm{A}}$ & $\alpha \alpha \alpha \alpha / \alpha \alpha$ & $\mathrm{C} / \mathrm{T}$ \\
\hline III-3 & $F / 25$ & 3.1 & 6.2 & 66.1 & 20.3 & 3.8 & 6.7 & $\beta^{39} / \beta^{\mathrm{A}}$ & $\alpha \alpha \alpha \alpha / \alpha \alpha$ & $\mathrm{C} / \mathrm{C}$ \\
\hline II-4 & $\mathrm{F} / 21$ & 3.3 & 7.4 & 70.9 & 22.4 & 2.1 & 17.9 & $\beta^{39} / \beta^{\mathrm{A}}$ & $\alpha \alpha \alpha \alpha / \alpha \alpha$ & $\mathrm{C} / \mathrm{C}$ \\
\hline II-5 & $\mathrm{M} / 19$ & 4.6 & 14.7 & 93.2 & 32.1 & 2.2 & 1.6 & $\beta^{\mathrm{A}} / \beta^{\mathrm{A}}$ & $\alpha \alpha / \alpha \alpha$ & $\mathrm{C} / \mathrm{T}$ \\
\hline \multicolumn{11}{|l|}{ Family 2} \\
\hline $\mathrm{I}-1$ & $\mathrm{M} / 25$ & 6.1 & 12.3 & 65.7 & 20.3 & 5.2 & 1.4 & $\beta^{39} / \beta^{\mathrm{A}}$ & $\alpha \alpha / \alpha \alpha$ & $\mathrm{C} / \mathrm{C}$ \\
\hline $\mathrm{I}-2$ & $\mathrm{~F} / 25$ & 5.3 & 10.2 & 65.0 & 19.1 & 4.9 & 6.7 & $\beta^{\mathrm{del} /} \beta^{\mathrm{A}}$ & $\alpha \alpha / \alpha \alpha$ & $\mathrm{C} / \mathrm{T}$ \\
\hline II-1 & $F / 5$ & 3.8 & 9.8 & 88.3 & 26.1 & 0.5 & 80.5 & $\beta^{39} / \beta^{\text {del }}$ & $\alpha \alpha / \alpha \alpha$ & $\mathbf{C} / \mathbf{T}$ \\
\hline \multicolumn{11}{|l|}{ Family 3} \\
\hline I-1 & $\mathrm{M} / \mathbf{2 8}$ & 3.6 & 7.1 & 82.0 & 19.9 & 7.8 & 8.7 & $\beta^{39} / \beta^{+132}$ & $\alpha \alpha / \alpha \alpha$ & $\mathrm{C} / \mathrm{C}$ \\
\hline II-1 & $\mathrm{F} / 7$ & 6.2 & 11.8 & 58.0 & 19.1 & 6.3 & 3.4 & $\beta^{39} / \beta^{\mathrm{A}}$ & $\alpha \alpha / \alpha \alpha$ & $\mathrm{C} / \mathrm{C}$ \\
\hline II-2 & $\mathrm{M} / 1$ & 4.2 & 10.7 & 76.7 & 25.2 & 3.6 & 8.4 & $\beta^{\mathrm{A}} / \beta^{+132}$ & $\alpha \alpha / \alpha \alpha$ & $\mathrm{C} / \mathrm{C}$ \\
\hline
\end{tabular}

$\mathrm{RBC}=$ red blood cells; $\mathrm{Hb}=$ hemoglobin; $\mathrm{MCV}=$ mean corpuscular volume; $\mathrm{MCH}=$ mean corpuscular hemoglobin; $\mathrm{HbA}_{2}=$ hemoglobin $\mathrm{A}_{2} ; \mathrm{HbF}=$ fetal hemoglobin; $\beta^{39}=H B B:$ c. $118 \mathrm{C}>\mathrm{T} ; \beta^{\mathrm{del}}=H B B 3$ ' deletion; $\beta^{+132}=H B B: c . * 132 \mathrm{C}>\mathrm{A}$. Index cases are shown in bold. $*=H B G 2: \mathrm{c} .-211 \mathrm{C}>\mathrm{T}(X m n 1-158 \mathrm{C}>$ $\mathrm{T}) . \dagger$ Transfused during sample collection. $\S$ Deceased after diagnosis.

types of both parents we observed a classical $\beta^{0}$ allele carrier phenotype in the father (I-1) and her mother (I-2).

By Sanger sequencing of $H B B$ gene in the proband, we observed the mutation $H B B$ : c. 118C > T (p.Gln39*) (or $\beta 39 \mathrm{C}>\mathrm{T}$ ) inherited from her father. The second molecular defect identified in the index case, inherited by her mother, was a deletion of the 3' end of the $H B B$ gene, comprising the third exon and the 3' UTR of $H B B$. This deletion comprises the loss of a segment between 0.6 and $10.6 \mathrm{~Kb}$ : $11 p 15.4$ (5193650-5202711) (5203314-5204229) (Figure 1B). Therefore the $\beta^{39 \mathrm{C}>\mathrm{T}} / \beta^{\mathrm{del}}$ genotype explains the thalassemia intermedia phenotype. Both parents were simple heterozygotes, the father $\beta^{39 \mathrm{C}>\mathrm{T}} / \beta^{\mathrm{A}}$, and the mother $\beta^{\mathrm{del}} / \beta^{\mathrm{A}}$.

Family 3

The propositus is a 28-year-old male patient with $\beta$-thal intermedia phenotype, elevated $\mathrm{HbF}(8.7 \%)$ as well, and an unusual increment of $\mathrm{HbA}_{2}(7.8 \%)$. His 7-year-old daughter presented a typical $\beta^{0}$ thalassemia carrier phenotype, with considerably elevated $\mathrm{RBC}$ and increased $\mathrm{HbA}_{2}$ $(6.3 \%)$. Moreover, his one-year-old son presented a mild anemia $(10.7 \mathrm{~g} / \mathrm{dL})$ with elevated $\mathrm{HbF}(8.4 \%)$, with microcytosis and slightly increased $\mathrm{HbA}_{2}(3.6 \%)$.

The molecular analysis by Sanger sequencing of the $H B B$ gene revealed the presence of two single nucleotide mutations in compound heterozygosity condition in the propositus: c. $118 \mathrm{C}>\mathrm{T}\left(\mathrm{p} . \mathrm{Gln} 39^{*}\right)($ or $\beta 39 \mathrm{C}>\mathrm{T})$ and c. ${ }^{*} 132 \mathrm{C}>\mathrm{A}$ (Figure $\left.1 \mathrm{C}\right)$. The c. $118 \mathrm{C}>\mathrm{T}$ mutation was transmitted to his daughter (II-1) and the other mutation, c. ${ }^{*} 132 \mathrm{C}>\mathrm{A}$, to his son (II-2).

\section{Discussion}

Beta thalassemia is one of the most commonly studied genetic diseases. It is mainly attributed to single nucleotide mutations in the $H B B$ gene, however, association with other globin gene mutations such as $H B A 2$ and $H B A 1$ triplication is often observed. In Mexican individuals, a previous report observed the presence of $-\alpha^{3.7}$ and $\alpha \alpha \alpha^{\text {anti3.7 }}$ in $16 \%$ and $28 \%$ respectively of $\beta$-thal carriers (Nava, et al., 2006). The pathophysiology of $\beta$-thal is related to the unbalanced ratio of $\alpha / \beta$-globin chains caused by the reduced $\left(\beta^{+}\right)$, or absent $\left(\beta^{0}\right) \beta$-globin synthesis and the relative excess of free $\alpha$-globin chains. In this paper we report three Mexican families with beta thalassemia intermedia due to different molecular defects.

In the first family, we detected the presence of a single $\beta^{0}$ allele $(H B B: c .118 \mathrm{C}>\mathrm{T})$ in the proposita and two sisters, whose phenotype resembles thalassemia intermedia since they all have severe but non-transfusion dependent anemia and elevated $\mathrm{HbF}$. In five members of the family (I-1, II-1, II-2, II-3 and II-4), we observed the presence of an $\alpha$-globin genes duplication encompassing the regulatory HS-40 region. Their hematological data were consistent with previous reports of families carrying one $\beta^{0}$-thal allele along with an $\alpha$-cluster duplication (Harteveld et al., 2008; 
Ben-Salah et al., 2017; Clark et al., 2018; Theodoridou et al., 2018). It is known that co-inheritance of $\alpha$ deletions represents a benefit for $\beta$-thal patients; on the other hand, increased $\alpha$-globin chains due to genes duplication in $\beta$ thal patients leads to a more severe phenotype (Mettananda et al., 2015; Saleh-Gohari et al., 2015; Shang and Xu 2017). Several studies demonstrate the common association of $\alpha$-globin gene duplications and a single $\beta$-thal allele as a cause of $\beta$-thal intermedia (Origa et al., 2014). To date, there are ten genetic rearrangements that end in additional copies of one or both alpha-globin genes including the worldwide-distributed $3.7 \mathrm{~kb}$ and $4.2 \mathrm{~kb}$ triplications (Clark et al., 2018). The duplication reported in this study is larger than duplicated segments previously reported. Additional molecular and/or cytogenetic testing such as a Comparative Genome Hybridization could help to understand the origins and exact location of these genetic variants.

The second family presented also thalassemia intermedia phenotype, however, their molecular basis included two $\beta$ globin gene mutations: the typical $H B B . c: 118 \mathrm{C}>\mathrm{T}$ and a new uncharacterized deletion involving the 3' end of $H B B$ gene. This deletion causes the loss of the third exon, therefore may produce a short unstable mRNA that could undergo early degradation. This early degradation mechanism is typical for mutations inducing a premature termination codon in coding sequences (Grosso et al., 2008; Rawa et al., 2017). It is important to notice the unusual increased $\mathrm{HbF}$ in the mother, who is a simple heterozygote for this deletion. Aside the high $\mathrm{HbF}$ level she presents a classical $\beta^{0}$ thal allele carrier phenotype. There is a large number of deletions in the $\beta$-cluster that are associated with elevated $\mathrm{HbF}$, nevertheless, these deletions usually involve the complete loss of gamma, delta and/or beta genes (Andersson et al., 2007; Thein and Wood, 2009; Pissard et al., 2013). The particular deletion reported in this study causes the loss of third exon and the possible loss of the $H B B$ 3' regulatory region (DNase I hypersensitive site; LOC110006319; Gene ID: 110006319), which includes multiple GATA1 binding protein sequences (https://www.ncbi.nlm.nih.gov/gene/107133510). Here again, further research is required to determine the exact breakpoints.

Although it is known that the loss of the 3' regulatory sequences in $H B B$ does not alter its own expression, little is known about its relationship with adult $H B G 2$ and $H B G 1$ expression (Bender et al., 2006; Reading et al., 2016). Several deletions concerning the $\beta$-globin gene cluster have been reported (Mettananda and Higgs, 2018; Thein 2013). They are classified in three main groups: those that remove the LCR (Locus Controlling Region); others that remove partially or totally the $\beta$-cluster genes $\left(\varepsilon \gamma \delta \beta^{0}\right.$-thalassemia, $\gamma \delta \beta^{0}$-thalassemia, $\delta \beta^{0}$-thalassemia); and deletions that involve partial or complete loss of the $\beta$-gene, such as, the Asian/Indian 619 bp deletion of $H B B$ 3' end, the $\approx 45 \mathrm{~kb}$ Fil- ipino deletion that removes the entire $\beta$-gene, and the recently reported 5 ' $\beta$-globin gene deletions of $538 \mathrm{bp}$ and 1517 bp (Waye et al., 1994; Patrinos et al., 2004; Shooter et al., 2015; Waye et al., 2017;).

Concerning the third family, in this paper we report for the first time a single nucleotide mutation involving the last nucleotide of the $\beta$ RNA transcript, a transversion C > A in the position c.*132. This mutation was observed in a 28-year-old male patient in compound heterozygosity with $H B B:$ c. $118 \mathrm{C}>\mathrm{T}$. Given the patient's hematological data we infer the possible pathological effect of this mutation. Additional evidence was provided by his son data, who is a simple heterozygote for this allele and presents microcytic hypochromic features with elevated $\mathrm{HbA}_{2}$ typical of a beta-thalassemia trait (Table I). This mutation involves the last nucleotide of the HBB transcript, located nearly $20 \mathrm{bp}$ upstream the poly-A signal (https://www.ncbi.nlm.nih.gov/gene/3043) and has a possible disrupting effect on transcription and RNA maturation processes. To our knowledge, there is a report of another transition in the same position $(* 132 \mathrm{C}>\mathrm{T})$ associated with c. $92+1 \mathrm{G}>\mathrm{A}$ in a patient with $\beta$-thal intermedia phenotype (Bilgen et al., 2013). Although the patient's phenotype reveals a clear evidence of the pathological effect of this mutation, further transcription and mRNA analysis are required for establishing said effect. It has come to our interest the unusual elevated $\mathrm{HbA}_{2}$ in this family (I-1 and II-2). Usually, this particular feature is associated with $\beta$ gene promoter deletions or single nucleotide mutations that involve CACCC, CCAAT or TATA elements (Thein 2018). In both of these patients, sequence analysis showed no mutations in $H B B$ promoter.

$H B G 2:$ c. $-211 \mathrm{C}>\mathrm{T}$ polymorphism was observed in heterozygosity in three members of the first family with normal HbF (I-2, II-2 and II-5, Table 1), and two members of the second family with elevated $\mathrm{HbF}$ (I-2 and II-1, Table 1 ), therefore, the effect of this variant on the induction of $\gamma$-globin chains cannot be easily explained in these Mexican families.

Beta thalassemia intermedia is a widely variable disease, although the vast majority of mutations are associated to $\beta$ globin gene, other genes can be involved. For this reason, it is important not to despise other genetic factors, such as other globin genes $(\alpha, \gamma$ or $\delta)$ or genetic variants located outside the globin gene clusters. Additional genomic approaches could clarify the etiology, as well as the clinical heterogeneity of this pathology.

\section{Conclusions}

We report for the first time three Mexican families with beta thalassemia intermedia due to different molecular defects. Likewise, we report a new single nucleotide mutation $\left(H B B:\right.$ c. $\left.^{*} 132 \mathrm{C}>\mathrm{A}\right)$ involving the last nucleotide of the $\beta$-globin chain transcript; as well for the first time in 
Mexican population, two possible new DNA rearrangements, an $\alpha$ cluster duplication that includes both $\alpha$ genes, and a partial $\beta$ gene deletion. $H B B$ : c. $118 \mathrm{C}>\mathrm{T}$ mutation is the most frequent $\beta$-thal allele in Mexican population (Rizo-de la Torre et al., 2017), for this reason it is not surprising to find its association with other mutations as a main cause of $\beta$-thal intermedia. $\beta$-thal intermedia is supposed to be uncommon in our population, whereas $\beta$-thal carriers are rather frequent suggesting that this condition might be underdiagnosed therefore it is important to identify unusual or new variants that could lead to complex cases of hemoglobinopathies.

\section{Acknowledgments}

This work was supported by a studentship from Programa para el Desarrollo Profesional en Investigación Internacional de Estudiantes de Posgrado/Fondo de Investigación en Salud/Instituto Mexicano del Seguro Social (PRODESI/FIS/IMSS 2016) who was recieved by BC and BPN in Hôpital La Timone. MRC Holland provided charitably SALSA MLPA P140 HBA and P102 HBB probemixes 50 rxn, and SALSA MLPA EK1 reagent kit 100 rxn FAM.

\section{Conflict of interest}

The authors declare no conflict of interest.

\section{Authorship}

RTLC performed the research, analyzed the data and wrote the paper, PDFJ designed the research study, contributed essential reagents, analyzed data and wrote the paper, ICB designed the research study, analyzed data, wrote the aper, RLVM performed the research, SLJY analyzed data, wrote the paper, SAFJ derived patients and collected clinical data, MTMT provided essential tools and wrote the paper, GK performed the research, $\mathrm{BC}$ designed the research study, contributed essential reagents and tools, BPN designed the research study, analyzed data, wrote the paper. All authors made substantial contributions to research design, or the acquisition, analysis or interpretation of data; drafted the paper and revised it critically; and approved the submitted version.

\section{References}

Andersson BA, Wering ME, Luo HY, Basran RK, Steinberg MH, Smith HP and Chui DH (2007) Sickle cell disease due to compound heterozygosity for $\mathrm{Hb} \mathrm{S}$ and a novel 7.7-kb betaglobin gene deletion. Eur J Haematol 78:82-85.

Ben-Salah N, Bou-Fakhredin R, Mellouli F and Taher AT (2017) Revisiting beta thalassemia intermedia: past, present, and future prospects. Hematology 22:607-616.

Bender MA, Byron R, Ragoczy R, Telling A, Bulger M and Groudine MF (2006) HS-62.5 and 3'HS1, and regions up- stream of the LCR, are not required for $\beta$-globin transcription. Blood 108:1395-1401.

Bilgen T, Clark OA, Ozturk Z, Akif-Yesilipek M and Keser I (2013) Two novel mutations in the 3' untranslated region of the beta-globin gene that are associated with the mild phenotype of beta thalassemia. Int J Lab Hem 35:26-30.

Clark B, Shooter C, Smith F, Brawand D, Steedman L, Oakley M, Rushton P, Rooks H, Wang X, Drousiotou A et al. (2018) Beta thalassemia intermedia due to co-inheritance of three unique alpha globin cluster duplications characterised by next generation sequencing analysis. $\mathrm{Br} \mathrm{J}$ Haematol 180:160-164.

Grosso M, Palumbo I, Morelli E, Puzone S, Sessa R and Izzo P (2008) Defective mRNA levels are responsible for a betathalassemia phenotype associated with Hb Federico II, a novel hemoglobin variant [beta-106 (G8) Leu- > Val]. Haematologica 93:1096-1098.

Harteveld CL, Refaldi C, Cassinerio E, Cappellini MD and Giordano PC (2008) Segmental duplications involving the $\alpha$ globin gene cluster are causing $\beta$-thalassemia intermedia phenotypes in $\beta$-thalassemia heterozygous patients. Blood Cells Mol Dis 40:312-316.

Huisman THJ and Jonxis JHP (1977) The hemoglobinopathies techniques of identification. Marcel Dekker Inc., New York, $464 \mathrm{p}$.

Liu YT, Old JM, Miles K, Fisher CA, Weatherall DJ and Clegg JB (2000) Rapid detection of alpha-thalassemias deletions and alpha-globin gene triplication by multiples polymerase chain reactions. Br J Haematol 108:295-299.

Mettananda S, Gibbons RJ and Higgs DR (2015) $\alpha$-Globin as a molecular target in the treatment of $\beta$-thalassemia. Blood 125:3694-3701.

Mettananda S and Higgs DR (2018) Molecular basis and genetic modifiers of thalassemia. Hematol Oncol Clin North Am 32:177-191.

Miller SA, Dykes DD and Polesky HF (1988) A simple salting out procedure for extracting DNA from human nucleated cells. Nucleic Acids Res 16:1215.

Nava MP, Ibarra B, Magaña MT, Chávez ML and Perea FJ (2006) Prevalence of $-\alpha 3.7$ and $\alpha \alpha \alpha$ anti3.7 alleles in sickle cell trait and $\beta$-thalassemia patients in Mexico. Blood Cells Mol and Dis 36:255-258

Ngo DA and Steinberg MH (2015) Genomic approaches to identifying targets for treating $\beta$ hemoglobinopathies. BMC Med Genomics 8:44.

Old JM, Varawalla NY and Weatherall DJ (1990) Rapid detection and prenatal diagnosis of $\beta$-thalassemia: studies in Indian and Cyprot population in the UK. Lancet 336:834-837.

Origa R, Sollaino MC, Borgna-Pignatti C, Piga A, Feliu-Torres A, Masile V and Galanello R. (2014) $\alpha$-globin gene quadruplication and heterozygous $\beta$-thalassemia: a not so rare cause of thalassemia intermedia. Acta Haematol 131:162-164.

Patrinos GP, Giardine B, Riemer C, Miller W, Chui DHK, Anagnou NP, Wajcman H and Hardison RC (2004) Improvements in the HbVar database of human hemoglobin variants and thalassemia mutations for population and sequence variation studies. Nucl Acids Res 32:D537-541.

Pissard S, Raclin V, Lacan P, Garcia C, Aguilar-Martinez P, Francina A and Joly P (2013) Characterization of three new 
deletions in the $\beta$-globin gene cluster during a screening survey in two French urban areas. Clin Chim Acta 415:35-40.

Rawa K, Szczesny RJ, Owczarek EP, Adamowicz-Salach A, Klukowska A, Demkow U, Plochocka D, Szczesny P, Gora M, Dziembowski A et al. (2017) Two novel C-terminal frameshift mutations in the $\beta$-globin gene lead to rapid mRNA decay. BMC Medical Genetics 18:65.

Reading NS, Shooter C, Song J, Miller R, Agarwal A, Lanikova L, Clark B, Thein SL, Divoky V and Prchal JT (2016) Loss of major DNase I hypersensitive sites in duplicated $\beta$-globin gene cluster incompletely silences $H B B$ gene expression. Hum Mutat 37:1153-1156.

Rizo-delaTorre LC, Ibarra B, Sánchez-López JY, Magaña-Torres MT, Rentería-López VM and Perea-Díaz FJ (2017) Three novel $H B B$ mutations, c. $-140 \mathrm{C}>\mathrm{G}(-90 \mathrm{C}>\mathrm{G})$, c.237_256delGGACAACCTCAAGGGCACCT (FS Cd 78/85-20 bp), and c.315+2T > G (IVS2:2 T > G). Update of the mutational spectrum of $\beta$-Thalassemia in Mexican mestizo patients. Int J LabHem 39:539-545.

Saleh-Gohari N, Khademi-Bami M, Nikibakht R and KarimiMaleh H (2015) Effects of $\alpha$-thalassemia mutations on the haematological parameters of $\beta$ thalassemia carriers. J Clin Pathol 68:562-566.

Shang X and Xu X (2017) Update in the genetics of thalassemia: What clinicians need to know. Best Pract Res Clin Obstet Gynaecol 39:3-15.

Shooter C. Rooks H, Thein SL and Clark B (2015) Next generation sequencing identifies a novel rearrangement in the HBB cluster permitting to-the-base characterization. Hum Mutat 36:142-150.

Sripichai O and Fucharoen S. (2016) Fetal hemoglobin regulation in $\beta$-thalassemia: heterogenity, modifiers and therapeutic approaches. Expert Rev Hematol 9:1129-1137.
Thein SL (2013) The molecular basis of $\beta$-thalassemia. Cold Spring Harb Perspect Med 3:a011700.

Thein SL (2018) Molecular basis of $\beta$ thalassemia and potential therapeutic targets. Blood Cells Mol Dis 70:54-65.

Thein SL and Wood WG (2009) The molecular basis of $\beta$ thalassemia, $\delta \beta$ thalassemia, and hereditary persistence of fetal hemoglobin. In: Steinberg MH, Forget BG, Higgs DR, Weatherall DJ (eds) Disorders of the hemoglobin: genetics, pathophysiology, and clinical management. Cambridge University Press, New York, pp 323-356.

Theodoridou S, Vyzantiadis TA and Vlachaki E (2018) Compound heterozygosity for silent cap $+1570(\mathrm{~T}>\mathrm{C})$ (HBB:c*96T > C), codon $39(\mathrm{C}>\mathrm{T})(\mathrm{HBB}: \mathrm{c} .118 \mathrm{C}>\mathrm{T})$ and the presence of $\alpha \alpha \alpha^{\text {anti-3.7 }} / \alpha \alpha$ in Greece. A case presentation. Hemoglobin 12:1-2.

Vives-Corrons JL, Pujades MA, Miguel-García A, Miguel-Sosa A and Cambiazzo S (1992) Rapid detection of Spanish $(\delta \beta) 0$-thalassemia deletion by polymerase chain reaction. Blood 80:1582-1585.

Waye JS, Eng B, Hunt JA and Chui DH (1994) Filipino beta-thalassemia due to a large deletion: identification of the deletion end points and polymerase chain reaction (PCR)-based diagnosis. Hum Genet 5:30-532.

Waye JS, Hanna M, Hohenadel BA, Nakamura L, Walker L and Eng B (2017) Characterization of Two Novel Deletions Involving the 5 ' Region of the $\beta$-Globin Gene. Hemoglobin 41:239-242.

Zhong L, Gan X, Xu L, Liang C, Xie Y, Lin W, Chen P and Liu M (2018) The phenomena of balance defect between $\alpha$-globin gene and of $\beta$-globin gene. BMC Med Genet 19:145.

Associate Editor: Luis F.Z. Batista

License information: This is an open-access article distributed under the terms of the Creative Commons Attribution License (type CC-BY), which permits unrestricted use, distribution and reproduction in any medium, provided the original article is properly cited. 